\title{
Teaching Model Construction for English Intensive Reading from the Perspective of Implicit Ideological and Political Education
}

\author{
Chu Yan", Sun Jiazhen, Wang Yibo, Wang Xu
}

English Department, Foreign Language School, North China Electric Power University, Baoding, Hebei, China

DOI: $\underline{\text { 10.36348/jaep.2020.v04i09.002 }}$ | Received: 09.09.2020 | Accepted: 17.09 .2020 | Published: 30.09 .2020

*Corresponding author: Chu Yan

Abstract

The introduction of ideological and political ideas into university education is an important measure to clarify the goal of China's education development, recognize the inherent laws of education, clarify the characteristics and significance of China's education, and innovate the means of education. As an important foreign language course in universities, English intensive reading courses should constantly explore effective ways to combine foreign language with ideology and politics. This study mainly adopts the way of building teaching plan model, which will focused on the design of teaching plan, the unit theme, group tasks, autonomous learning, evaluation system, and other aspects. There is still much room for thinking and improving on how to construct "foreign language with ideological and political education" under the framework of "implicit ideological and political education".

Keywords: Construction of ideological and political teaching model; Implicit Ideological and political education; English intensive reading.

Copyright @ 2020: This is an open-access article distributed under the terms of the Creative Commons Attribution license which permits unrestricted use, distribution, and reproduction in any medium for non-commercial use (NonCommercial, or CC-BY-NC) provided the original author and sources are credited.

\section{Status Quo of Ideological and Political Education in College Foreign Language Courses}

The construction and development of colleges and universities has gradually become the main aspect of carrying out education in the new era. The combination of college curriculum and ideology and politics is one of the most effective ways to guide college students' thoughts onto the right track. As early as 2016, President Xi proposed to "make all kinds of courses go along with ideological and political theory courses" [1]. Ideological and political course is the main channel of systematic ideological and political education in moral education courses [2]. Therefore, scholars have also made great efforts in curriculum reform. The reform of curriculum ideological and political construction realizes the creative transformation from the main channel of "ideological and political curriculum" to the "ideological and political curriculum" all-round three-dimensional education by digging deeply into the moral factors of specialized courses and public courses and promoting the integration of explicit education and implicit education [3]. But in the past, ideological and political education are not often found integrated with other courses [4]. At this stage, college students are in the era of rapid development of science and technology and globalization, which determines the complex structure and rich connotation of college students' values, and their values are experiencing unprecedented contradictions in thought. Without faith, values will be lost, and individuals will even lose their moral conscience [5]. Foreign language courses, especially intensive reading courses are an important channel for college students to learn about the world and current events at home and abroad, so it is of vital importance to vigorously promote the combination of English courses and ideological and political education.

From a macro point of view, the effective combination of ideological and political education and intensive reading needs a subtle, implicit method. In China, many scholars are actively exploring in this field, hoping to find some efficient ways to improve the quality of college English education. Liu Jing proposed that colleges and universities should build the curriculum system based on "for whom to train", complete the system in the light of the problem of "how to train", and improve the system in the process of reform and innovation [6]. Universities in Shanghai have also made many beneficial attempts in ideological and political education practice. Since 2014, a number of "China series" brand courses have been launched, such as "Understand China" of Shanghai Jiaotong University, "The Chinese Path" of Tong Ji University, 
Chu Yan et al., J Adv Educ Philos, September, 2020; 4(9): 387-391

"Innovation in China" of Shanghai University, etc. These courses keep up with the times and have been "hot courses" [7]. Through the above, we find that these explorations are relatively successful. However, it seems that no scholar has done any research on how to combine ideological and political education with intensive reading and established a micro teaching model for reference. This paper will take a unit in intensive reading class (Fresh Start) as an example to establish a course teaching model from a micro perspective, and it is expected that this model can be used as a reference for the course implementation.

\section{Curriculum Design \\ Theme of the unit}

The accurate lead-in of the theme is a key link in the combination of the education teaching and ideological and political education. Teachers need to have a precise understanding and profound analysis of the theme before class, analyze the theme and convert the content to which students can effectively understand. In the process, if the teacher could teach in a way that conforms to the students' cognitive range and daily life, to choose and purposefully sublimate into a form of philosophy and politics which have a correct guidance of students' world view, philosophy and value, then the effect of guiding students to form correct values, ideals and beliefs, and moral beliefs by the way of basic text teaching.

Therefore, we should attach great importance to how to combine unit themes with ideology and politics, and imperceptibly make students understand them effectively in class.

\section{Method of Lead-in}

This part is mainly based on the textbook of English Intensive Reading, taking a specific unit as an example, to carry out the theme lead-in mode construction of the whole ideological and political teaching from the micro perspective.

Fresh Start focuses on the author's first day's experience at college, which makes herself embarrassed, but finally she realizes that she cares too much about these things and becomes mentally mature. This is in the opening paragraph: "My plan was to keep my ears open and my mouth shut and hope no one would notice I was a freshman."

The ideological details here should be paid attention and teachers are required to put forward questions for themselves:

\begin{tabular}{|l|}
\hline Does this place resonate with students? \\
\hline How did the students in this class think on their first day of college? \\
\hline Can we increase interaction and exchange ideas here? \\
\hline Is this a good place to lay the groundwork for the central idea and theme below? \\
\hline Should it be emphasized here that students need to keep a positive attitude at the beginning of the semester? \\
\hline
\end{tabular}

The teacher should pause here to let the students speak out their feelings and have a collision with the students' thoughts so as to know more about the feelings of the students to explain the text much more clearly and effectively and throw out the central theme by bringing teachers themselves into the feelings of the students.

There are two mistakes the author made on her first day of school that she found embarrassing. The teacher could divide the text into two parts when interpreting and leave some pauses between them for discussion with students, and the second sub-theme is introduced after both events are finished. The purpose of doing this is to give students enough time to have a comprehensive understanding and thinking about its connotation of two events with similar or identical ideas, which plays a better auxiliary role for the introduction of the theme later.

The last thing that the author encounters is a boy who also falls in the same cafeteria. This is a shocking to the author, which is also makes the author saw herself at that time from an outsider's perspective, and finally realized that she had been thinking too seriously and caring too much about her mistake before.
Here the teacher should notice that the last event leads naturally to what the author sees as the central theme of the text. So, after finishing the last story, the teacher needs to pay attention to draw the theme line naturally and bring out the central theme. After that, it is necessary to sublimate the theme and guide the correct value, in order to achieve the final work of combining the whole text with ideological and political education. Only the text be explained in this intensively reading way can In order to truly integrate ideological and political elements into the classroom and "moisten things silently" to have a positive impact on students, to guide and cultivate the formation of students' correct ideas so as to realize the organic integration of ideology and politics with classroom teaching.

It is worth teachers' attention that, when the theme is introduced, parts of the text should be divided according to the event or content level, and different levels of ideas should be extracted from several different parts. Even the hierarchy can be more obvious, so that the level gradually improved, the idea is also gradually in-depth. In the process of theme introduction, teachers should keep in mind that there cannot be too many parts and sub-themes, two or three 
will be enough, also, the sub-themes must be consistent with the central theme of the text and unit (except the extended theme of the article here), the role of each sub-theme is clear -- laying the foundation for the central theme, leading to the central theme.

\section{"Sparks Collision of Thinking" teaching mode}

The extension of theme is also a part that cannot be ignored by teachers. The extension of theme focuses on the students' deep understanding and application of the content and subject idea of the text and unit, as well as the effective degree of teachers' explanation of the theme and the leading effect on students' thought.

The setting of theme extension is realized by the teaching mode of "Sparks Collision of Thinking". The teaching mode of "Sparks Collision of Thinking" is realized through the interaction between students and teachers, also between students and students, which can also be said to be the interactive link of thinking. In this teaching mode, teachers leave students thinking questions in class, and give students enough time to read, comprehend and think about the themes that can be extended to text or unit. Then everyone writes the thought on a piece of paper, including the teacher, all the students and the teacher exchanged the pieces paper or both the students and the teacher handed in the pieces of paper to be randomly selected. At the end of the activity, each one needs to get a piece of paper of someone else's. On account of each student has his own thinking and idea, after this, they know what others are thinking, this would lead to a mind-collision effect, so as to say, a sparks collision of thinking happened. Everyone's thoughts collide and communicate with each other in virtually, resulting in everyone's progress and improvement. To achieve this effect is the purpose of our research on this new "Sparks Collision of Thinking" teaching mode.

\section{Group Task}

Group task is a very important part of foreign language education in college. This method of dividing students into groups to complete tasks can not only promote students' cooperation and mutual help, but also improve their dialectical thinking ability, so that students can generate inspiration in the collision of ideas between peers. Similarly, to combine intensive reading with ideological and political work, group work is also an indispensable method. Group task can be used in many notions of the course, and students can be guided to get close to each other in ideological and political aspects independently. In this way, students will not only get bored, but also have a good opportunity to communicate and learn from each other. In the Fresh Start, there are many sections where grouping task can be added, depending on the teaching procedures.
For example, in the sixth paragraph of the first text, after the author met something embarrassing in the canteen, there is a description of the performance of the bystanders. The description is lifelike and shows the attitude of the bystander, which is one of the reasons why the author feels so embarrassed. If the teacher accuses the bystander in the text stiffly when he tells this detail, it violates the principle of implicit ideology and politics. In fact, in this sentence, the teacher can add a group to discuss the task in class, asking "What kind of psychological state would you be if you were an onlooker?" or "Are you going to help her?". Such questions will trigger discussions, guide them to think and boldly speak out their own views, and then make a summary to instruct students to deal with such things correctly. Combined with the results of the questionnaire survey, it is found that such practice not only creates the atmosphere and makes students memorize deeply, but also inputs a kind of correct approach subtly and enables students to form correct values.

\section{Guidance for Autonomic Learning}

Of all the teaching process, the autonomic learning part is the most effective, but also the most difficult to supervise. In order to cultivate students' ability of independent learning, teachers often give them enough time and space for research, but they often indulge students too much, which may lead to students' boredom and aversion to independent learning. We sent out relevant questionnaires and collected more than 90 sample data. According to the survey, 68 percent of students want guidance on ideals and beliefs in intensive reading classes. Therefore, if the autonomic learning can be combined with "strong beliefs", then the effect must be twice the result with half the effort.

In the whole unit Fresh Start, there is a good part as the autonomous learning task -- TEXT 2: A Universities Stands and Shines. This article uses a lot of description and sentences to highlight the importance of university. If students can dig into this article independently, they probably have a new understanding of their college life in the future. When teachers are designing the teaching plan of this article, they can put forward some topics like "Do you think the university described in the article is consistent with what you think?", In doing so, students can read the article while thinking. After the students give a speech or other presentation in the next class, teachers can give guidance. Through the questionnaire survey, $66 \%$ of the students are interested in comparison between Chinese and western culture, hence teachers can also find some domestic and foreign news materials or documentaries to broadcast in class according to the similarities and differences between Chinese and Western universities, and hold a small class activity similar to a seminar, so as to give students the space to fully express themselves. These methods of assisting students to study independently can not only play a supervisory 
role, but also make students more impressed by this article. Even if teachers do not illustrate on them, students can have their own reflection.

\section{Examination and Evaluation}

Examination and evaluation are the last part of each unit. This part requires the cooperation of teachers and students. For students, it is necessary to review the knowledge of each unit and summarize the topic. For teachers, this part is a good opportunity to test students' mastery of knowledge, from which they can get a more comprehensive understanding of students' performance and proficiency.

Since students have carefully digested and internalized the knowledge of each unit in self-learning and group tasks, we mainly focus on discussing issues related to the theme of each unit. We expand the theme of each unit, and students have in-depth thinking, and then show their views through oral presentation and writing.

So, our model is the following steps.

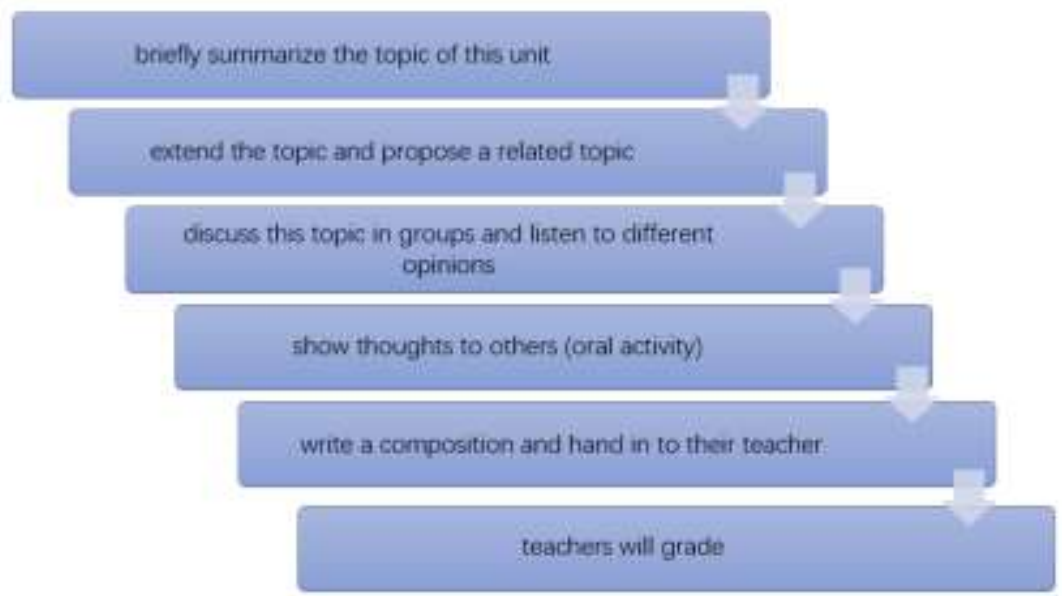

The teacher or students briefly summarize the topic of the unit firstly, the second is that the teacher extends the topic, and proposes a related topic, then students discuss this topic in groups and listen to other people's different opinions, and they need to show their thoughts to others (oral activity). Finally, they will write a composition, which should be handed in to their teacher. Teachers will grade according to the students' presentations and composition in class.

In this part, students' opinions are the most important. Teachers should take students' thoughts into consideration. Therefore, the teacher's grading criteria likes that.

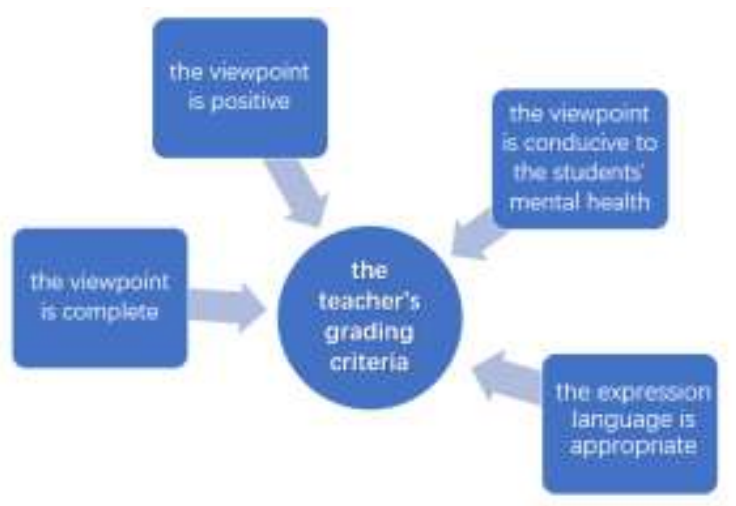

Teachers need to consider that whether the viewpoint is complete, whether the viewpoint is positive, whether the viewpoint is conducive to the students' mental health, and whether the expression language is appropriate. We hope students can learn more helpful information and establish positive values from this part.
Take fresh start as an example. By showing the experience of freshmen, this article inspires people to be themselves and not excessively pursue perfection. As a result, according to this theme, the teacher may quote the saying "To err is human, to forgive divine." Do you really believe that one could be forgiven for moral or behavioral defects? Or do you believe that one can live a perfect life without making any mistakes? 
Students need to give an oral presentation and a composition. Then their teacher will grade.

\section{CONCLUSION}

The research presented in this paper is under the premise of the combination of language teaching and ideological and political education. It is a full ideological and political education teaching mode analyzed from various micro perspective of lesson plan design, unit theme, group task, independent learning, assessment and evaluation based on a specific unit of the language teaching course. It is hoped that the teaching mode constructed in this study could be of certain reference significance to the teachers who have this need for language teaching and also the implementation of combining language teaching with ideological and political education.

At the same time, our holistic study has made great efforts to fit in with the new situation of current education and siding "the whole staff nurtures the human, the entire process nurtures the human, omnidirectional nurtures the human "three entire" nurtures the human pattern, aiming at cultivating all-round talents. It is our hope that in the way of taking advantage of this new teaching mode of the curriculum of language teaching is integrated with ideological and political education we can cultivate students and more of them with a sound, advanced set of values, ideals and beliefs, and moral beliefs, which could lay a certain talent foundation for development.

\section{REFERENCES}

1. Yang, F., Pu, X., \& Zou, Q. (2018). Integrating Ideological and Political Education into Foreign Language Teaching [C]. China Academic Journal Electronic Publishing House.

2. Shi, S. Correctly Grasp the Relationship between Curriculum Ideological and Political Courses [J]. Ideological and theoretical education, 18(11):5761.

3. Yang, H. (2018). From "Courses of Ideological and Political Education" to "Ideological and Political Course" -- On the breakthrough point of the reform of ideological and political theory course in Shanghai universities [J]. Journal of Yangzhou University, 22(02):98-104.

4. Deng, H., \& Yan, W. (2016). From "Courses for Ideological and Political Education" to "Courses of Ideological and Political Education" -- The Exploration of the Construction of a Comprehensive Ideological and Political Teaching System in Shanghai [N]. Guangming Daily, 12(8).

5. Yang, F., Pu, X., \& Zou, Q. (2018). Integrating Ideological and Political Education into Foreign Language Teaching [C]. 650500, DOI:10.16400/j.cnki.kjdkz.2018.12.036.

6. Liu, J. The Construction and Exploration of College Foreign Language Curriculum System under the Ideological and Political Concept [C]. China Academic Journal Electronic Publishing.

7. Wang, Y., Li, Y., Zhang, J., \& Zhai, J. Exploration and Practice of cons Foreign Language Education as an Example [C]. China Academic Journal Electronic Publish. 